\title{
The Effects of Destination Image, Perceived Value, and Service Quality on Tourist Satisfaction and Word-of-Mouth - A Study in Ho Chi Minh City, Vietnam
}

\author{
Mai Ngoc Khuong and Nguyen Thanh Phuong
}

\begin{abstract}
In recent years, the number of international tourists who revisit Vietnam is relatively low, at $32.98 \%$ [1]. Therefore, being considered as an effective way to attract new visitors, tourist's word-of-mouth was the main concern of the current research. This study attempted to examine the effects of destination image, perceived value and perceived service quality, which were believed to have direct relationships with individuals' perception, on tourist destination satisfaction and WOM behaviour, in order to further suggest recommendations for tourism industry. Quantitative approach was mainly applied, using a questionnaire which was directly delivered to 1,673 foreign tourists in Ho Chi Minh City (HCMC), Vietnam. The results showed that destination image, perceived value, and perceived service quality were significantly correlated and had both directly and indirectly effects on WOM through the mediation of destination satisfaction. Suggestions were given to develop a favourable image of HCMC, improve service quality and increase tourists' perception of value received in accordance to perceived price/cost, which in turn, would enhance their satisfaction and motivate WOM activities.
\end{abstract}

Index Terms-Destination image, perceived value, service quality, tourist Word-of-Mouth, tourist destination satisfaction.

\section{INTRODUCTION}

Tourism is identified as one of the most important economic sectors, which contributes significantly to the development of a country. Although tourism in Vietnam has grown, all the advantages are not utilized thoroughly and reasonably to promote Vietnam, especially Ho Chi Minh City (HCMC) as a top destination choice. Indeed, HCMC faces an intense problem that not many tourists return after their first visit. Statistics from [1] showed that $32.98 \%$ of foreign tourists returned to the country at least once, in comparison to $55 \%$ of tourists revisit Thailand. In another research project by [2], which investigated the number of English-speaking re-visitors at five destinations in Vietnam (Sapa, Halong, Hue, Danang, Hoian), only $11.2 \%$ of total tourists return to the same destination at least once. Two main reasons contribute to the small number of revisitors. Firstly, domestic tourism industry is not highly-concentrated; all sectors are not linked to serve tourists and negative attributes are still not under control [3]. Secondly, as a subjective reason, people tend to visit another destination or recommend the previous rather

Manuscript received July15, 2017; revised October 8, 2017.

Mai Ngoc Khuong and Nguyen Thanh Phuong are with the School of Business, International University - VNU-HCM, Vietnam (e-mail: mnkhuong@hcmiu.edu.vn, phuong.ng1903@gmail.com). than revisit [4], [5]. Therefore, considering revisit intention and/or recommendation as two consequences of tourist loyalty [5], [6] tourist recommendation or word-of-mouth to attract new visitors is more likely a better strategy to push sales in tourism.

In addition, surveys by [7] showed that only $23.9 \%$ visitors perceived that price of goods was cheap and $38.9 \%$ perceived that quality of service in Vietnam was good. It means Vietnamese goods were perceived as neither cheaper nor better than goods from other markets. Reference [8] claimed that such destination factors as attractions, facilities and services did not have any direct impacts on tourist destination. Instead, these factors influenced satisfaction through the perceive of value and quality. Indeed, destination image, perceived value and service quality are variables that have direct relationships with tourists since the concepts are subjective and they truly reflect tourists' perception. Therefore, it can be inferred that these three are important determinants to evaluate the satisfaction level and word-of-mouth behaviour of tourists in HCMC.

\section{LITERATURE REVIEW}

\section{A. Tourist Destination Satisfaction}

This concept can be explained by the combination of two definitions, which are "a subjective perception, evaluation, or judgment held by customers based on their experience with a service performance rather than a firm's objective standards of quality" [9] and as an individual's cognitive-affective state derived from a consumer experience [10]. In this study, tourist satisfaction is investigated as the result of tourists' image, value and quality perception so it is unique to each individual. Meanwhile, the emotion and cognitive judgment are both directly related to personal experience during the trip at HCMC.

Different methods to measure customer satisfaction have been introduced, discussed and adapted. Generally, they can be classified into two main approaches: disconfirmation theory and performance only [11]. The first one is based on the gap between expectations and perceived performances to determine satisfaction [12]. However, some authors criticize the accuracy of this approach such as personal bias and problems with measuring expectations [13]. The second approach is through the evaluation of destination's attributes, which researchers choose to establish their own model [11], [14], [15]. Reference [16] pointed out that by using the sum of attribute evaluations, researchers can only measure "attribute 
satisfaction" [17], while "overall satisfaction" is another concept explained as "an overall evaluation based on the total purchase and consumption experience with a good or service over time" [18]. In this context, attribute and overall satisfaction are all concerned to explore tourist satisfaction toward both the destination's attributes and the whole trip after travelling.

\section{B. Word-of-Mouth}

Word-of-mouth (WOM) can be understood quite differently in two cases: consumer WOM and WOM as a marketing communication method of companies. Reference [19] described WOM communication as an exchange of comments, thoughts and ideas among two or more individuals in which none of them represent a marketing source. Additionally, some authors linked WOM to interpersonal influence [20], which is the power to influence others; they argued that since consumers imitate and talk to each other, WOM can be seen as a way they share information, in which the sources are independent of commercial influence. In this context, WOM is concerned as the consequence of tourist destination satisfaction so these tourists play the communicator role to recommend others about HCMC.

In many studies, WOM is considered as a common form of loyalty behaviour toward attractions [5], [6] and as a consequence of tourist satisfaction [21]-[23]. Indeed, WOM is an essential concept since it is believed to be among the most powerful communication channels, with more potential impact on consumers than traditional advertising [24], [25]. In tourism, positive WOM has an impact on purchase/travel decisions [26] and people tend to follow their family, friends, and colleagues' recommendation [25], [27]. In addition, WOM certainly helps increase the number of tourists and eventually, increase profits at no marketing cost [28] if tourists are all willing to recommend to their friends, relatives, and other potential travelers.

\section{Destination Image}

Destination image was found to have an impact on many aspects such as tourist destination satisfaction [29], loyalty [30], travel decision-making [31], [32] as well as behavioural intention [33], [34]. One of the most traditional definitions for the concept is "an expression of all objective knowledge, impressions, prejudices, imaginations and emotional thoughts an individual or a group have of a particular location" [35]. Furthermore, from the review of other definitions [36], it can be seen that the key words behind the concept are "perceptions of tourists" toward a destination, which mean destination image is subjective to a certain level.

Two most common components of destination image are cognitive and affective aspects [37], [38]. In general, cognitive evaluations refer to an individual's knowledge, impressions, perceptions, ideas and beliefs about an object, while affective evaluations are related to tourists' feelings toward that object. Cognitive dimensions are more preferred to measure destination image [39] and they vary in different research model to reflect different characteristics of a specific destination that the researcher is testing [31], [40]. Furthermore, some researchers argue the third component of destination: conative aspects, which is the action component of image such as visit/revisit intention or recommendation [41], [42].

\section{Perceived Value}

Perceived value is an important antecedent of satisfaction and has direct positive relationship with customer satisfaction in tourism industry [34], [43]. Reference [44] defined it as "the consumer's overall assessment of the utility of a product based on perceptions of what is received and what is given". It can be further explained in relation to pricing as the distance between customer perceptions of what is received (utility derived from quality) and what is sacrificed (price and other costs) [45]. So, in general tourist perceived value is measured by the gap between the sum of customers' benefits and the total sacrifices (expenditures/time/effort) for taking the trip.

Besides measuring value only in accordance to price/money, many authors have used different ways to develop a set of dimensions to conceptualize and measure value as a multi-dimensional construct (Table I). In this study, the scale [46] is also known as the PERVAL scale, fully reflect tourists' perception through feeling, judgment, personal gain and value in relation with cost and time.

TABLE I: Dimensions for MEASURING PERCEIVED VALUE

\begin{tabular}{|c|c|}
\hline Authors & Dimensions/Scales \\
\hline [47] & $\begin{array}{l}\text { Functional, Emotional, Conditional, Social and } \\
\text { Epistemic }\end{array}$ \\
\hline$[48]$ & $\begin{array}{l}\text { Extrinsic versus Intrinsic, Self-Oriented versus } \\
\text { Other-Oriented and Active versus Reactive }\end{array}$ \\
\hline [46] & $\begin{array}{l}\text { Emotional, Social and two types of Functional } \\
\text { Value (Price/Value for Money and } \\
\text { Performance/Quality). }\end{array}$ \\
\hline [49] & Hedonic and Utilitarian values \\
\hline
\end{tabular}

\section{E. Perceived Service Quality}

Perceived service quality is argued to be an antecedent of satisfaction in both service industry [50]-[52] and in the field of tourism [53]. In specific, higher service quality tends to increase customer satisfaction [54], [55]. The most common definition of this concept is from [51], who viewed perceived service quality as the gap between customers' expectations of a service and their perceptions of the actual performance they received. However, reference [56] broadly defined perceived service quality as the consumer's judgment and evaluation regarding the superiority of a service. Therefore, perceived service quality can be defined by two ways based on how it is measured: expectation versus experience and personal evaluation or perception.

SERVQUAL [51] with five dimensions: Reliability, Assurance, Tangibles, Empathy, and Responsiveness, is a well-known instrument developed to measure quality. However, there are some controversial ideas surrounding the use and effectiveness of it [57], [58]. Many researchers have adapted and modified the model to have better result in their context [59], [60]. In addition, reference [57] suggested using consumer perceptions to measure perceived quality, which is consistent with the mentioned intention of this research.

- H1: Destination image, perceived value and perceived service quality directly affect tourist destination satisfaction. 
- H2: Destination image, perceived value and perceived service quality and tourist destination satisfaction directly affect word-of-mouth.

- H3: The effect of destination image, perceived value and perceived service quality on word-of-mouth is mediated by tourist destination satisfaction.

\section{Methodology}

\section{A. Research Design and Data Collection}

This research mainly applied quantitative approach to examine the effects between variables. Target population was all foreign tourists who had stayed at least two days in HCMC and convenience sampling method was applied. The questionnaire was translated into English, Korean, Japanese and Chinese corresponding with four largest groups of international tourists in Vietnam; totally, 1673 responses were collected. For data analysis, First, Exploratory Factor Aanalysis (EFA) and Reliability Test were conducted to identify the interrelationships among a set of research variables and to ensure the reliability and validity of them. Subsequently, Multiple Regression and Path Analysis were employed to explore the causal relationships among variables, and then confirm the research hypotheses.

Items in the questionnaire were based on literature reviews and adapted to the research context. Particularly, TODESA and PERSEQUA were adopted from [11]; WOM was adapted from the concept of loyalty intentions [61]. The questions were in form of Five-scale Likert statements $(1=$ strongly disagree, 5 = strongly agree), with one open-ended question for better recommendation. Surveys were delivered and collected by two main ways: directly from tourists and indirectly through tour guides.

\section{B. Sample Size}

In this study, standard error selected for the collected continuous data was $e=2.5 \%$. Thus, with the number of international tourist visiting HCMC equals $N=4,600,000$ and $95 \%$ confidence level, the sample size will be calculated as:

$$
n=\frac{\mathrm{N}}{1+\mathrm{N}(\mathrm{e})^{2}}=\frac{4.600 .000}{1+4.600 .00(.025)^{2}}=1,599
$$

\section{Factor Analysis and Reliability}

For the group of independent variables (Table II), the eigenvalues of three factors were all greater than 1 and total variance explained was $56.54 \%$. KMO was .908 , indicating the suitability of the data for principal component analysis [62] and Barlett's test of sphericity value was significant $(p=.000)$, showing sufficient correlation between variables for further test. Cronbach's Alphas were all high (from .759 to .847), displaying high reliability.

TABLE II: SUMMARY OF INDEPENDENT VARIABLES

\begin{tabular}{lcc}
\hline \hline Variables & $\begin{array}{c}\text { Number } \\
\text { of items }\end{array}$ & $\begin{array}{c}\text { Alpha } \\
(N=1,673)\end{array}$ \\
\hline Perceived Value (PERVA) & 6 & .827 \\
Perceived Service Quality (PERSEQUA) & 5 & .847 \\
Destination Image (DESIMA) & 5 & .759 \\
\hline \hline
\end{tabular}

Similarly, the group of two dependent variables (Table III) accounted for $58.35 \%$ of the total variance with Cronbach's Alphas of .611 and .814. KMO value was .788 and Barlett's test of sphericity reached significant level of $p=.000$. Therefore, all factors in the research model were meaningful and reliable for further analysis.

TABLE III: SUMMARY OF DEPENDENT VARIABLES

\begin{tabular}{lcc}
\multicolumn{2}{c}{ TABLE III: SUMMARY OF DEPENDENT VARIABLES } \\
\hline \hline Variables & $\begin{array}{c}\text { Number } \\
\text { of items }\end{array}$ & $\begin{array}{c}\text { Alpha } \\
(N=1,673)\end{array}$ \\
\hline Tourist Destination Satisfaction (TODESA) & 4 & .611 \\
Tourist Word-of-Mouth (TOWOM) & 3 & .814 \\
\hline \hline
\end{tabular}

\section{RESEARCH FINDINGS}

\section{A. Demographic Characteristics of Respondents}

TABLE IV: DEMOGRAPHICS OF PARTICIPANTS

\begin{tabular}{|c|c|c|c|}
\hline & & $\begin{array}{l}\text { Frequency } \\
\text { (N) }\end{array}$ & Valid \% \\
\hline \multirow{3}{*}{ Gender } & Male & 893 & 53.4 \\
\hline & Female & 780 & 46.6 \\
\hline & Total & 1,673 & 100.0 \\
\hline \multirow{7}{*}{ Age } & Below 18 & 34 & 2.0 \\
\hline & $18-25$ & 419 & 25.0 \\
\hline & $26-30$ & 405 & 24.2 \\
\hline & $31-40$ & 387 & 23.1 \\
\hline & $41-60$ & 310 & 18.5 \\
\hline & Above 60 & 118 & 7.1 \\
\hline & Total & 1,673 & 100.0 \\
\hline \multirow{7}{*}{ Nation } & Europe & 529 & 31.6 \\
\hline & USA / Canada & 193 & 11.5 \\
\hline & Latin America & 26 & 1.6 \\
\hline & Asia & 777 & 46.4 \\
\hline & Australia, NZ & 136 & 8.1 \\
\hline & Africa & 12 & .7 \\
\hline & Total & 1,673 & 100.0 \\
\hline \multirow{6}{*}{ Education } & High-School degree & 191 & 11.4 \\
\hline & College degree & 233 & 13.9 \\
\hline & Studying University & 250 & 14.9 \\
\hline & Bachelor degree & 646 & 38.6 \\
\hline & Master degree or higher & 353 & 21.1 \\
\hline & Total & 1,673 & 100.0 \\
\hline \multirow{5}{*}{$\begin{array}{l}\text { Time }(s) \text { of } \\
\text { visit }\end{array}$} & 1 & 1,085 & 64.9 \\
\hline & 2 & 256 & 15.3 \\
\hline & 3 & 122 & 7.3 \\
\hline & More than 3 & 210 & 12.6 \\
\hline & Total & 1,673 & 100.0 \\
\hline \multirow{5}{*}{$\begin{array}{l}\text { Purpose of } \\
\text { visit }\end{array}$} & Business & 251 & 15.0 \\
\hline & Leisure & 1,052 & 62.9 \\
\hline & Visiting Friends/Family & 177 & 10.6 \\
\hline & Other & 193 & 11.5 \\
\hline & Total & 1,673 & 100.0 \\
\hline
\end{tabular}

From Table IV, the number of male participants was rather higher than female ( $53.4 \%$ compared to $46.6 \%$ ). The majority almost equally fell into three groups of age: 18-25 (25\%), $26-30(24.2 \%)$ and $31-40(23.1 \%)$, following by the group of 41-60 (18.5\%), which indicated that tourists from young adults to middle-aged were all target customers of tourism industry. Nearly half of respondents were Asian (46.4\%), while European, USA/Canadian and Australian/New Zealand accounted for $31.6 \%, 11.5 \%$ and $8.1 \%$ respectively. For education, tourists with bachelor and master degrees or higher made up the largest proportion (59.7\% in total), then 
university students with $14.9 \%$. Most tourists had come to HCMC for the first time $(64.9 \%)$ and for travelling purpose $(62.9 \%)$. However, this number decreased for the second $(15.3 \%)$ and third time $(7.3 \%)$ then surprisingly raised to $12.6 \%$ for "more than three times". It can be explained by the group of tourists who combined their trip with business purpose $(15 \%)$ so they travelled back and forth many times.

\section{B. Correlations between Variables}

TABLE V: PEARSON CORRELATIONS BETWEEN VARIABLES

\begin{tabular}{lccccc}
\hline \hline & TOWOM & 1 & 2 & 3 & 4 \\
\hline 1. PERVA & .710 & 1.000 & & & \\
2. PERSEQUA & .529 & .587 & 1.000 & & \\
3. DESIMA & .468 & .570 & .518 & 1.000 & \\
4. TODESA & .446 & .455 & .467 & .360 & 1.000 \\
\hline Mean & 3.942 & 3.877 & 3.757 & 3.938 & 3.539 \\
\hline SD & .765 & .646 & .677 & .615 & .622 \\
\hline \hline
\end{tabular}

Note: All correlations are significant at the .05 level $(p=.000)$

From Table V, it can be seen that all variables were positively correlated with each other. Among them, the highest effect was between PERVA and TOWOM ( $r=.710$, $p<.05)$, implying the more value tourists perceived from the trip, the more likelihood they would tell others about HCMC. Other variables including PERSEQUA, DESIMA and TODESA also had positive relationship with TOWOM ( $r=.529 ; r=.468$ and $r=.446$ respectively). In addition, three independent factors showed moderate correlations with the mediator TODESA (ranging from $r=.360$ to $r=.467$ ), indicating the predictive power of these factors on tourist satisfaction.

\section{Testing Hypotheses}

To test three groups of hypotheses, two multiple regression were first carried out between three independent factors and TODESA (H1), TOWOM (H2); then path analysis and bootstrapping method were used to prove indirect and total effect on TOWOM (H3).

\section{1) Factors directly affecting tourist destination satisfaction}

TABLE VI: EFFECT COEFFICIENTS BETWEEN IVS AND TODESA

\begin{tabular}{lcll}
\hline \hline Variables & $\begin{array}{l}\text { Unstandardized } \\
\text { Coefficients (B) }\end{array}$ & $\mathrm{t}$ & Sig. \\
\hline PERVA & 1.353 & 14.358 & .000 \\
PERSEQUA & .237 & 8.809 & .000 \\
DESIMA & .262 & 10.609 & .000 \\
\hline \hline
\end{tabular}

Note: Dependent Variable: TODESA: Tourist Destination Satisfaction

- Predictors: Perceived Value, Perceived Service Quality, Destination Image - ANOVA: $\mathrm{F}(3,1669)=206.663$, Sig. $=.000, p<.05$

- Model summary: $R^{2}=.271$

Table VI showed that all three explanatory factors PERVA, PERSEQUA and DESIMA had significant positive effect on TODESA with coefficients of $B=.237(p<.05), B=.262$ $(p<.05)$ and $B=.072 \quad(p<.05)$ respectively. It can be concluded that when tourists' perceptions of value, quality and the city image during the trip were positive, they would be more satisfied with HCMC.

2) Factors directly affecting tourist word-of-mouth

TABLE VII: EFFECT COEFFICIENTS BETWEEN IVS, TODESA AND TOWOM

\begin{tabular}{lcll}
\hline \hline Variables & $\begin{array}{l}\text { Unstandardized } \\
\text { Coefficients (B) }\end{array}$ & $\mathrm{t}$ & Sig. \\
\hline & .129 & 1.313 & .189 \\
PERVA & .661 & 24.450 & .000 \\
PERSEQUA & .139 & 5.566 & .000 \\
DESIMA & .052 & 1.989 & .047 \\
TODESA & .147 & 6.106 & .000 \\
\hline \hline
\end{tabular}

Note: Dependent Variable: TOWOM: Tourist Word-of-Mouth

- Predictors: Perceived Value, Perceived Service Quality, Destination Image, Tourist Destination Satisfaction

- ANOVA: $\mathrm{F}(4,1668)=479.757$, Sig. $=.000, p<.05$

- Model summary: $R^{2}=.535$

From Table VII, all coefficients were significant at $95 \%$ confidence level. Among three independent variables, PERVA had the largest direct effect on TOWOM ( $B=.661$, $p<.05$ ), which meant if tourists had enjoyed the trip and seen it worth their time and expenses, they would likely say good things about the destination. PERSEQUA ranked second $(B=.139, p<.05)$, followed by DESIMA $(B=.052, p<.05)$, indicating the satisfaction with quality and HCMC image would lead to the spread of WOM. In addition, the effect of TODESA with $\mathrm{B}=.147(p<.05)$ implied that the higher level of tourist satisfaction toward HCMC would result in the higher possibility of recommendation to others.

3) Indirect and total causal effects on tourist word-of-mouth

From two stages of multiple regression above, three independent variables were found to significantly affect both TODESA and TOWOM; TODESA was proven to directly affect TOWOM as well $(B=.147)$. The findings were summarized in Fig. 1. Therefore, through intervening variable of TODESA, three explanatory factors PERVA, PERSEQUA and DESIMA could be said to indirectly affect TOWOM at (.035), (.039), (.011) respectively.

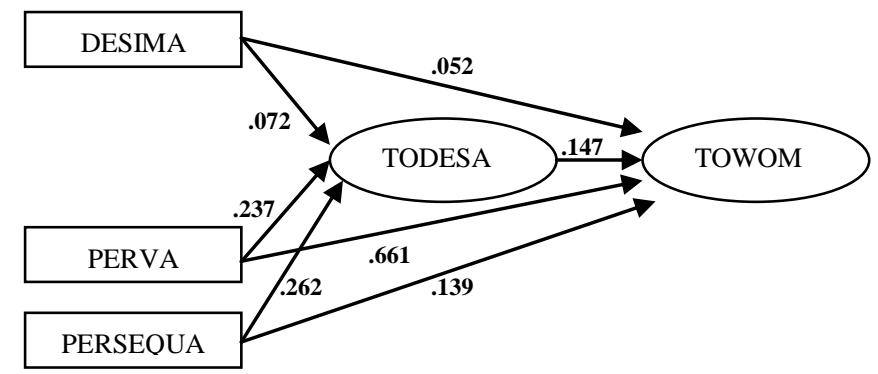

Note: All coefficients in the model are significant at 95\% confidence level. Fig. 1. Path coefficients of hypothesis testing.

Bootstrapping method was applied to confirm the significance of these indirect effects. The principle is by considering whether a zero (0) falls between the lower (LLCI) and upper (ULCI) boundary of the confidence intervals. If there is a zero, the indirect effect is not significant or no effect exists; on the contrary, indirect effect can be claimed [63]. According to Table VIII, the indirect effects of all PERVA, PERSEQUA and DESIMA were confirmed at $95 \%$ 
confidence interval. Among them, PERVA had the strongest effect on TOWOM with $B=.696$, which was a substantial effect [64]. Total effect of the model was 1.084 and the indirect effect was .085, which accounted for $7.84 \%$.

TABLE VIII: DIRECT, INDIRECT AND TOTAL CAUSAL EFFECTS ON TOWOM

\begin{tabular}{lccccc}
\hline \hline \multirow{2}{*}{ Variables } & \multicolumn{3}{c}{ Causal Effects } & \multirow{2}{*}{ LLCI } & ULCI \\
\cline { 2 - 4 } & Direct & Indirect & Total & & \\
\hline PERVA & .661 & .035 & .696 & .0240 & .0466 \\
\hline PERSEQUA & .139 & .039 & .178 & .0270 & .0509 \\
\hline DESIMA & .052 & .011 & .063 & .0038 & .0180 \\
\hline TODESA & .147 & --- & .147 & & \\
\hline Total & .999 & .085 & 1.084 & & \\
\hline \hline
\end{tabular}

\section{DISCUSSION, LIMITATION AND RECOMMENDATION}

\section{A. Discussions of the Findings}

This research aimed to determine the effects of PERVA, PERSEQUA and DESIMA on TODESA and TOWOM in order to give recommendations on how to enhance WOM behaviour. Therefore, three independent variables were examined as distinctive antecedents of satisfaction and TOWOM rather than the chain effect of "Destination Image Quality - Value - Satisfaction - WOM" [34], [65]. The results showed both similarities and differences in comparison to previous studies.

All three explanatory factors and TODESA were proven to have direct effects on TOWOM, which were consistent with other research [66], [67]. As tourists' travel-decision is motivated by the attraction of destination and personal desires, destination image and tourists' perception enhancement were believed to contribute to WOM activities [6].

Furthermore, indirect effect of these on TOWOM with the intervening variable TODESA also confirmed previous findings [66], [68]. In specific, reference [69] concluded that perceived value and service quality were two important dimensions to achieve a full understanding of satisfaction. Studies by [66] and [70] also supported that perceived value and service quality positively influenced tourist satisfaction. For DESIMA, it proved that both cognitive and affective destination image had positive relationship with overall tourist satisfaction [71]. These results highlighted the meaningful mediation of tourist destination satisfaction in linking tourists' perceptions and after-purchasing actions.

Among variables, PERVA carried the highest coefficients in both multiple regression stages, which implied its significant role in predicting satisfaction and WOM activities [34]. Given positive feeling towards HCMC and good experience earned from the trip, tourists would likely encourage friends to visit. In fact, this supported the common sense that when people scarified time and money in exchange for something and felt it totally deserved, they would be more excited to share their experience with others. A research by [72] proved both direct and indirect effects of PERVA on behavioral intentions, including word-of-mouth, through satisfaction.

For PERSEQUA, the proven direct and indirect effects on loyalty intentions such as WOM were similar to other studies, even though some used SERVQUAL model in measuring quality [73]. However, reference [34] only supported the indirect effect of trip quality on satisfaction mediated by perceived value, and suggested its uncertain indirect effect on future behaviours. Indeed, their research measured many aspects of quality such as price, transport, infrastructure, weather, safety while this one just focused on the perception of service quality in general as well as the reliability and profession. Therefore, it maybe the quality of service that was well perceived by tourists directly motivated their WOM behaviour.

Finally, DESIMA was found to positively affect TOWOM in this model [10], [74]; however, its effect was the lowest while it was reported in other research as playing a fundamental role in shaping tourist WOM [34], [75]. With the current situation, an increase in DESIMA only slightly push tourists to spread their WOM activities. It might be explained that the image of HCMC were not impressive enough to have a huge influence on tourists' willingness to introduce the destination to others.

\section{B. Limitations and Implications for Future Research}

Firstly, all items of DESIMA in the questionnaire were adapted and modified from the literature review, which might lead to the undesired effects on both TODESA and TOWOM. Furthermore, the p-value of DESIMA coefficient on TOWOM nearly reached insignificant level ( $p=.047)$. Future research can pay attention to investigate more destination attributes of HCMC by using both structured (quantitative) and unstructured (qualitative) to measure DESIMA [76].

Secondly, as mentioned in the literature review, both attribute and overall satisfaction were measured to best investigate tourist satisfaction; however, the result from EFA showed that only four items of satisfaction towards destination attributes were reliable. Therefore, the measurement scale must be improved to achieve the initial purpose. It is proposed that the model and questionnaire can be revised to test two stages of satisfaction [77], which proved the significant effect of attribute-specific satisfaction on overall satisfaction.

Thirdly, the research was limited in three independent variables, which were considered as having strong relationships with tourists' subjective perception. The model can further be extended by adding destination attributes as independent variables and PERVA, PERSEQUA will act as the first-level mediators [11]. This new combined model covers a large frame to better understand WOM behaviour and be able to give specific suggestions on improving the aspects that motivate tourists' willingness to recommend.

Fourthly, as a personal experience from data collecting process, tour-guided and self-guided tourists had quite different perceptions since the way they approached HCMC were not the same. It is suggested that "tourist type" be added to the demographic profile analysis to give appropriate recommendations to the target segmentation. In addition, it can be an inspiration for researchers to conduct further studies on these two types of tourists separately to capture the characteristics of each.

\section{Recommendations for Tourism Industry}

Based on the findings of this research and 128 comments 
from tourists, it is recommended that the authorities focus on building appropriate images for HCMC as well as enhance tourists' perceptions towards received value and service quality to increase destination satisfaction and WOM behavior. A destination with favorable images would increase its competitiveness and impress visitors. In fact, HCMC has great potential but these advantages are not utilized and promoted reasonably. Tourism attractions need to be upgraded and introduced along with their history. Particularly, places which are considered as the symbol of HCMC such as Ben Thanh Market must be well advertised and developed because choosing a good image to represent the city would make people easily recall the destination and attract more new visitors. Government budgets must be spent efficiently on building and promoting HCMC image as an active, modern and attractive city with a wide range of food, accommodation and entertainment choices.

Local cuisine is also an advantage as Vietnamese food is distinctive and diversified, especially street food. Some tourists regretted not having an opportunity to try all foods since they are not widely introduced. The government should have plans to gather these small food stalls or establish a "food town" where price, quality and hygiene are guaranteed to offer traditional dishes

For PERSEQUA, tourists' perception towards service quality and reliability need to be well shaped. The employees of the services should be professional in their serving, as well as keep a courteous, respectful and helpful attitude in front of customers. Hotel services, which were complained as boring and unprofessional (7\% tourists' comments) should concern more about concepts towards tourists. In facts, one of the most popular reasons for travel is gaining new experience. For example, Vietnamese food are introduced as discount price for tourists to try; vouchers or free tickets to visit famous places and enjoy unique services (e.g. water puppet shows) are offered. For medium to large sized hotels, traditional shows (e.g. singing, dancing) and games can be organized at the lobby every weekends for tourists to participate since they tend to be interested in what belongs to a country's uniqueness.

PERVA, which holds the highest value in this research finding, should be paid intense attention to push WOM activities. As PERVA was measured in the questionnaire by three groups of ideas, three approaches to increase PERVA are presented. Firstly, tourists would recommend HCMC if they perceived the beauty here and the positive feelings it brought. This factor can be improved through building a more favorable destination image and reducing negative attributes such as tricksters, thieves, beggars and street vendors as well as raising the level of safety and security in HCMC. Secondly, experience earned from the trip is an important indicator of value. This aspect can be enhanced by many ways, from a low level of tour design to an upper level of tourism management. For the tourism industry, more programs, festivals, shows and events to introduce Vietnamese history and culture need to be invested. Besides, even citizen, especially sellers, should understand Vietnamese tradition and culture so that they can provide tourists information when being asked.

Thirdly, tourist would be more satisfied if they felt that the trip was worth their expenses. Price discrimination was a serious matter because among tourists who mentioned about high price ( $7.8 \%$ tourists' comments); some even criticized this act as breaking the law in their countries. Therefore, it is imperative that the government and authorities take action to control price and protect buyers, especially tourists. It is proposed that businesses/sellers be compelled to publicize the price for all products and services that they provide and this price should be regularly checked by local supervisors to ensure it is reasonable. Furthermore, there should be a limited percentage which is allowed for businesses to raise price in special occasions and different price charged for foreigners must be strictly forbidden.

Last but not least, the low rate of local people who can communicate in English and other languages is also a weakness since $11.7 \%$ comments from tourists showed dissatisfaction with this. Language becomes a barrier for foreign tourists to approach Vietnam both in daily transaction and exploring Vietnamese lifestyle. Apart from assigning receptionists who are able to serve and give foreign tourists instructions at main halls of hotels, restaurants and sightseeing attractions, universalizing English at daily communication level for all employees is also encouraged. Indeed, it is a practical training part that not only upgrades tourism services to meet international standards, but also helps gain tourist satisfaction.

\section{CONCLUSION}

In conclusion, this research could achieve all the initial goals. In order to study the factors which motivate tourists to recommend HCMC to their friends and relatives, three independent variables namely destination image, perceived value and perceived service quality were taken into account, with the mediation of tourist destination satisfaction. The researcher was able to understand foreign tourists' perception toward HCMC, which in turn affects their satisfaction and word-of-mouth behavior.

From the sample of 1,673 responses, the significant correlations between and among variables in the model were claimed. Furthermore, all hypotheses were supported; in order words, both the direct and indirect effects of destination image, perceived value and perceived service quality on tourist word-of-mouth mediated by tourist satisfaction were claimed. Among them, perceived value was shown to have the highest total effect on tourist word-of-mouth $(B=.696$, $p<.05)$, followed by perceived service quality $(B=.178, p<.05)$ and destination image $(B=.063, p<.05)$. The similarities and differences in comparison to other studies were also discussed to see how this research would contribute the literature of tourism field.

Based on these findings, solutions could be proposed to improve the current problems of tourism industry, which in particular enhance tourist destination satisfaction and word-of-mouth behaviors through three factors: destination image, perceived value and perceived service quality.

\section{REFERENCES}

[1] Vietnam National Administration of Tourism. (2015). Công bố kết quả điều tra khách du lịch quốc tế đến Việt Nam năm 2014. [Online]. Available: http://vietnamtourism.gov.vn/index.php/items/17608 
[2] Environmentally and Socially Responsible Tourism Capacity Development Programme. (2014). 11,2\% khách quốc tế trở lại một điểm du lịch. Available: http://baochinhphu.vn/Thi-truong/112-khach-quoc-te-tro-lai-mot-die $\mathrm{m}$-du-lich/212886.vgp

[3] T. Nhi. (2015). Foreign Tourists Do Not Return to Vietnam Despite Many Top Attractions. Available: www.vietnambreakingnews.com/2015/06/foreign-tourists-do-not-retu rn-to-vietnam-despite-many-top-attractions/

[4] P. O. D. Valle, J. A. Silva, J. Mendes, and M. Guerreiro, "Tourist satisfaction and destination loyalty intention: A structural and categorical analysis," International Journal of Business Science and Applied Management, vol. 1, no. 1, pp. 25-44, 2006.

[5] T. H. Truong and B. King, "An evaluation of satisfaction levels among chinese tourists in Vietnam," International Journal of Tourism Research, vol. 11, no. 6, pp. 521-535, 2009.

[6] Y. Yoon and M. Uysal, "An examination of the effects of motivation and satisfaction on destination loyalty: A structural model," Tourism Management, vol. 26, no. 1, pp. 45-56, 2005.

[7] General Statistics Office, Results of Tourist Expenditure Survey in 2013, 2013.

[8] M. M. Okello and S. Yerian, "Tourist satisfaction in relation to attractions and implications for conservation in the protected areas of the Northern Circuit, Tanzania," Journal of Sustainable Tourism, vol. 17 , no. 5, pp. 605-625, 2009.

[9] T. C. Greenwell, J. S. Fink, and, D. L. Pastore, "Assessing the influence of the physical sportsfacility on customer satisfaction within the context of the service experience," Sport Management Review, vol. 5, no. 2, pp. 129-148, 2002.

[10] I. R. D. Bosque and H. S. Martin, "Tourism satisfaction: A cognitive-affective model," Annals of Tourism Research, vol. 35, pp. 551-573, 2008

[11] M. N. Khuong, N. T. H. An, and N. T. M. Uyen, "Direct and indirect effects on international tourists' destination satisfaction - The Case of the world natural heritage of Halong Bay, Vietnam," Journal of Economics, Business and Management, vol. 4, no. 2, pp. 85-91, 2016.

[12] A. Pizam and A. Milman, "Predicting satisfaction among first time visitors to a destination by using the expectancy disconfirmation theory," International Journal of Hospitality Management, vol. 12, no. 2, pp. 197-209, 1993.

[13] C. Gronroos, "Toward a third phase in service quality research Challenges and future directions," Advances in Service Marketing and Management: Research and Practice, vol. 2, pp. 49-64, 1993.

[14] T. H. Truong and D. Foster, "Using HOLSAT to evaluate tourist satisfaction at destinations: The case of Australian holidaymakers in Vietnam," Tourism Management, vol. 27, pp. 842-855, 2006.

[15] H. T. Tuan, "The factors affecting tourists' satisfaction at tourist attractions in Ho Chi Minh City," Journal of Science of Ho Chi Minh City University of Education, vol. 10, no. 76, pp. 87, 2015.

[16] R. L. Oliver, Satisfaction: A Behavioral Perspective on the Consumer, New York: Prince Hill, 1997.

[17] R. L. Oliver, "Cognitive, affective, and attribute bases of the satisfaction response," Journal of Consumer Research, vol. 20, pp. 418-430, 1993.

[18] E. W. Anderson, C. Fornell, and D. R. Lehmann, "Customer satisfaction, market share, and profitability: Findings from Sweden," Journal of Marketing, vol. 58, pp. 53-66, 1994.

[19] P. F. Bone, "Determinants of WOM Communication during Product Consumption," Advance in Consumer Research, vol. 19, pp. 579-583, 1992.

[20] S. W. Litvin, R. E. Goldsmith, and B. Pan, "Electronic Word-of-Mouth in Hospitality and Tourism Management," Tourism Management, vol. 29 , no. 3, pp. 458-468, 2008 .

[21] M. G. Gallarza and I. G. Saura, "Value dimensions, perceived value, satisfaction and loyaty: An investigation of University students' travel behaviour," Tourism Management, vol. 27, no. 3, pp. 437-452, 2006.

[22] P. O. D. Valle, J. A. Silva, J. Mendes, and M. Guerreiro, "Tourist satisfaction and destination loyalty intention: A structural and categorical analysis," International Journal of Business Science and Applied Management, vol. 1, no. 1, pp. 25-44, 2006.

[23] N. H. M. Salleh, R. Othman, T. Sarmidi, K. Zakaria, B. A. Talib, and S. H. M. Idris, "Tourist satisfaction and loyalty of Kapas Island Marine Park: A Structural Equation Model (SEM) analysis," Indian Journal of Geo-marine Science, vol. 43, no. 9, 2014.

[24] D. Godes and D. Mayzlin, "Using online conversations to study word-of-mouth communication," Marketing Science, vol. 23, no. 4, pp. $545-560,2004$
[25] H. S. Bansal and P. A. Voyer, "Word-of-mouth processes within a service purchase decision context," Journal of Service Research, vol. 3, no. 2, pp. 166-177, 2000.

[26] L. Murphy, G. Mascardo, and P. Benckendorff, "Exploring word-of-mouth influences on travel decisions: Friends and relatives vs. other travellers," International Journal of Consumer Studies, vol. 31, no. 5, pp. 517-527, 2007.

[27] M. Fakharyan, M. R. Jalilvand, M. Elyasi, and M. Mohammadi, "The influence of online word-of-mouth communications on tourists' attitudes toward Islamic destinations and travel intention: Evidence from Iran," African Journal of Business Management, vol. 6, no. 38, pp. 10381-10338, 2012

[28] L. Reid and S. Reid, "Communicating tourism supplier services: Building repeat visitor relationships," Journal of Travel \& Tourism Marketing, vol. 2, pp. 3-19, 1993.

[29] A. H. Khan, A. Haque, and M. S. Rahman, "What makes tourists satisfied? An empirical study on malaysian Islamic touris destination," Middle-East Journal of Scientific Research, vol. 14, no. 12, pp. 1631-1637, 2013.

[30] M. Jamaludin, S. Johari, A. Aziz, K. Kayat, and A. R. M. Yusof, "Examining structural relationship between destination image, tourist satisfaction and destination loyalty," International Journal of Independent Research and Studies, vol. 1, no. 3, pp. 89-96, 2012

[31] P. C. Fakeye and J. L. Crompton, "Image differences between prospective, first time and repeat visitors to the Lower Rio Grande Valley," Journal of Travel Research, vol. 30, pp. 10-16, 1991.

[32] E. Bigné, I. Sánchez, and S. Sanz, "The functional-psychological continuum in the cognitive image of a destination: A confirmatory analysis," Tourism Management, vol. 30, no. 5, pp. 1-9, 2009.

[33] G. Assaker, V. E. Vinzi, and P. O'Connor, 'Examining the effects of novelty seeking, satisfaction, and destination image on tourists' return pattern: A two factor, non-linear latent growth model," Tourism Management, vol. 32, no. 4, pp. 890-901, 2011.

[34] C. Chen and D. Tsai, "How do destination image and evaluative factors affect behavioral intention?" Tourism Management, vol. 28, pp. $1115-1122,2007$

[35] F. Lawson and M. Baud-Bovy, Tourism and Recreational Development, London: Architectural Press, 1977.

[36] H. San Martin and, I. A. R. Del Bosque, "Exploring the cognitive-affective nature of destination image and the role of psychological factors in its formation," Tourism Management, vol. 29 , no. 2, pp. 263-277, 2008.

[37] S. Baloglu and D. Brinberg, "Affective images of tourism destinations," Journal of Travel Research, vol. 35, no. 4, pp. 11-15, 1997.

[38] D. J. Walmsley and M. Young, "Evaluative images and tourism: The use of perceptual constructs to describe the structure of destination images," Journal of Travel Research, vol. 36, no. 3, pp. 65-69, 1998.

[39] L. Jun, A. Faizan, and G. K. Woo, "Reexamination of the role of destination image in tourism: An updated literature review," e-Review of Tourism Research, vol. 12, no. 3/4, pp. 191-209, 2015.

[40] A. Beerli and J. D. Martin, "Factors influencing destination image," Annals of Tourism Research, vol. 31, no. 3, pp. 657-681, 2004.

[41] W. Gartner "Image formation process," Journal of Travel and Tourism Marketing, pp. 191-216, 1994.

[42] S. Stepchenkova and J. Mills, "Destination image: A meta-analysis of 2000-2007 research," Journal of Hospitality Marketing \& Management, vol. 19, no. 6, pp. 575-606, 2010.

[43] M. N. Khuong and P. D. Luan, "Factors affecting tourists' satisfaction towards Nam Cat Tien National Park, Vietnam-A Mediation Analysis of Perceived Value," International Journal of Innovation, Management and Technology, vol. 6, no. 4, pp. 238-243, 2015.

[44] V. A. Zeithaml "Consumer perceptions of price, quality and value: A means-end model and synthesis of evidence," Journal of Marketing, vol. 52, no. 7, pp. 2-22, 1988.

[45] R. Leszinski and M. V. Marn. Setting value, not price. The McKinsey Quarterly. [Online]. Available: www.mckinsey.com/insights/marketing_sales/setting_value_not_pric $\mathrm{e}$

[46] J. C. Sweeney and G. N. Soutar, "Consumer perceived value: The development of a multiple item scale," Journal of Retailing, vol. 77, no. 2, pp. 203-220, 2001.

[47] J. N. Sheth, B. I. Newman, and B. L. Gross, "Why we buy what we buy: A theory of consumption values," Journal of Business Research, vol. 22, no. 2, pp. 159-170, 1991.

[48] M. B. Holbrook, "Introduction to consumer value," Consumer Value: A Framework for Analysis and Research, pp. 1-28, 1999. 
[49] K. Ryu, H. Han, and S. Jang "Relationships among hedonic and utilitarian values, satisfaction and behavioral intentions in the fast-casual restaurant industry," International Journal of Contemporary Hospitality Management, vol. 22, no. 3, pp. 416-432, 2010.

[50] R. L. Oliver, "Whence customer loyalty?" Journal of Marketing, vol. 63, pp. 33-44, 1999.

[51] A. Parasuraman, V. A. Zeithaml, and L. L. Berry, "SERQUAL: A multiple item, scale for measuring consumer perceptions of service quality," Journal of Retailing, vol. 64, no. 1, pp. 12-40, 1988.

[52] P. Y. Chu, G. Y. Lee, and Y. Chao, "Service quality, customer satisfaction, customer trust, and loyalty in an e-banking context," Social Behavior and Personality: an International Journal, vol. 40, no. 8, pp. 1271-1283, 2012.

[53] S. Lee, S. Jeon, and D. Kim, "The impact of tour quality and tourist satisfaction on tourist loyalty: The case of Chinese tourists in Korea," Tourism Management, vol. 32, no. 5, pp. 1115-1124, 2011.

[54] D. Baker and J. Crompton, "Quality, satisfaction and behavioral intentions," Annals of Tourism Research, pp. 785-804, 2000.

[55] E. Bigné, M. A. Moliner, and J. Sánchez, "Perceived quality and satisfaction in multiservice organizations: The case of Spanish public services," Journal of Services Marketing, vol. 17, no. 4, pp. 420-442, 2003.

[56] V. A. Zeithaml and M. J. Bitner, Services Marketing: Integrating Customer Focus across the Firm, New York: McGraw Hill, 2000.

[57] J. J. Cronin and S. A. Taylor, "Measuring service quality: A re-examination and extension," Journal of Marketing, vol. 56, pp. $55-68,1992$.

[58] R. K. Teas, "Expectations as a comparison standard in measuring service quality: An assessment of a reassessment," Journal of Marketing, vol. 58, no. 1, pp. 132-139, 1994.

[59] S. Markovic and S. R. Jankovic, "Exploring the relationship between service quality and customer satisfaction in Croatian hotel industry," Tourism and Hospitality Management, vol. 19, no. 2, pp. 149-164, 2013.

[60] N. Petrovic, "Modified SERVQUAL Model of service quality measurement in hotels with business facilities," Center for Quality, 2013.

[61] A. Yuksel and F. Yuksel, "Shopping risk perceptions: effects on tourists' emotions, satisfaction and expressed loyalty intentions," Tour Manage, vol. 28, no. 3, pp. 703-713, 2007.

[62] J. Pallant, SPSS Survival Manual: A Step by Step Guide to Date Analysis Using SPSS Version 12, 2nd ed. Buckingham: Open University Press, 2005.

[63] J. K. Preacher and A. F. Hayes, "Asymptotic and resampling strategies for assessing and comparing indirect effects in multiple mediator model," Behavior Research Methods, vol. 40, no. 3, pp. 879-891, 2008.

[64] D. De Vaus, Analyzing Social Science Data, London: Sage, 2002.

[65] C. F. Chen and F. S. Chen, "Experience quality, perceived value, satisfaction and behavioral intentions for heritage tourists," Tourism Management, vol. 31, no. 1, pp. 29-35, 2010.
[66] M. M. Abdalla, J. R. Ribas, and, P. R. da Costa Vieira, "The antecedents of word of mouth intentions about a Brazilian tourist destination," Tourism and Management Studies, vol. 10, no. 1, pp. 104-111, 2014.

[67] M. Mohamad, A. Ghani, and N. Izzati, "The impact of tourist satisfaction on destination loyalty among European tourists visiting Malaysia," International Journal of Management Sciences, vol. 2, no. 8, pp. 362-371, 2014.

[68] M. Gallarza, I. Saura, and F. Moreno, "The quality-value-satisfaction-loyalty chain: Relationships and impacts," Tourism Review, pp. 3-20, 2013.

[69] G. H. McDougall and T. Levesque, "Customer satisfaction with services: Putting perceived value into the equation," Journal of Services Marketing, vol. 14, no. 5, pp. 392-410, 2000.

[70] S. M. Meng, G. S. Liang, and S. H. Yang, "The relationships of cruise image, perceived value, satisfaction, and post-purchase behavioral intention on Taiwanese tourist," African Journal of Business Management, vol. 5, no. 1, pp. 19-29, 2011.

[71] C. Wang and M. Hsu, "The relationship of destination image, satisfaction and behavioral intention: an integrated model," Journal of Travel and Tourism Marketing, vol. 27, no. 8, pp. 829-843, 2010

[72] D. Gill, B. Byslma, and R. Ouschan, "Customer perceived value in a cellar door visit: The impact on behavioural intentions," International Journal of Wine Business Research, vol. 19, no. 4, pp. 257-275, 2007.

[73] Y. Keshavarz and M. H. Ali, "The service quality evaluation in tourist loyalty in Malaysian Hotels by the mediating role of tourist satisfaction," Mediterranean Journal of Social Sciences, vol. 6, no. 3S2, pp. 680, 2015.

[74] C. Chi, and H. Qu, "Examining the structural relationship of destination image, tourist satisfaction and destination loyalty: An intergrated approach," Tourism Management, vol. 29, no. 4, pp. 624-636, 2008.

[75] J. E. Bigné, M. I. Sánchez, and J. Sanchez, "Tourism image, evaluation variables and after purchase behavior: Inter-relationship," Tourism Management, vol. 22, pp. 607-616, 2001.

[76] C. M. Echtner and J. Ritchie, "The measurement of destination image: An empirical assessment," Journal of Travel Research, vol. 31, no. 4, pp. 3-14, 1993.

[77] Y. J. Jin and F. P. James, "Measuring attribute-specific and overall satisfaction with destination experience," Asia Pacific Journal of Tourism Research, vol. 18, no. 5, pp. 409-420, 2013.

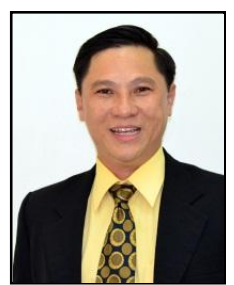

Mai Ngoc Khuong is a lecturer and researcher of School of Business Administration, International University, Vietnam National University, Ho Chi Minh City. He has bachelor degree in tourism and hospitality management, master of science degree in leisure, tourism and environment at Wageningen University, The Netherlands, and $\mathrm{PhD}$ degree in development management at School of Public Administration of the National Institute of Development Administration (NIDA), Bangkok, Thailand. 